\title{
Aging and Synaptic Plasticity: A Review
}

\author{
Jorge A. Bergado and William Almaguer \\ International Center for Neurological Restoration. Havana, Cuba
}

\section{SUMMARY}

Aging affects all systems, but the brain seems to be particularly vulnerable to the action of negative, age-dependent factors. A gradual loss of memory functions is one of the earliest and most widespread consequences of brain aging. The causes for such impairment are still unclear. Long-term potentiation (LTP) is one form of neural plasticity, which has been proposed as the cellular correlate for memory. LTP is affected by aging, and such alteration might be causally related to memory dysfunction. In the present paper, we review the evidence sustaining the existence of a causal link between cognitive and LTP impairments, as well as the possible mechanisms involved. New results indicate a possible involvement of a deficient reinforcement of LTP by affective influences.

\section{INTRODUCTION}

Aging, in biological or cosmological dimension, is the most evident consequence of the passing of time. Time is one of the coordinates (along with space) that form the referential frame in which we exist. It is difficult to assess whether time itself has any influence on living organisms. More probable are thermodynamically irreversible processes that

Prof. Jorge A. Bergado, International Center for Neurological Restoration (CIREN) Ave. 25 \# 1580511300 Playa Ciudad de La Habana, Cuba; e-mail: bergado@neubas.sld.cu occur in a timely organized sequence, those responsible for aging and for giving us the sense of the passing of time. In biological terms, the aging process is accompanied by a progressive multisystemic deterioration which, in the absence of other factors (like accidents or disease), inevitably leads to death.

Although there appears to be little hope at present of reaching immortality, major improvements in living conditions and medical care during the last century have brought a steady and significant lengthening of human life (at least for a part of mankind). Consequently, one of the main goals of modern science is to provide a better quality to those years added to life by retarding, reducing, or eliminating (when possible) the negative consequences of aging. Any progress in this direction will be based on a better understanding of the mechanisms involved in the progressive impairments accompanying aging.

The preservation of memory abilities, in both senses, namely, the ability to learn new information and to retrieve old contents, is among the most desired because it is precisely one of the more severely affected by aging. A widely accepted view at present attributes memory formation and consolidation to functional modifications at synapses in different regions of the brain. Whereas the brain system serving particular forms of memory (declarative, motor skills, emotional, classical conditioning, and others) might be different, the basic mechanism modifying synaptic efficacy seems to be common (Matthies, 1998; Medina et al., 2002; Milner et al., 1998). 
Long-term potentiation (LTP) of synaptic efficacy (Bliss \& Gardner-Medwin, 1973; Bliss \& Lomo, 1973) is a long-lasting increase in synaptic efficacy after high frequency (tetanic) stimulus, and appears as the best candidate mechanism for explaining the learning-induced changes in synaptic connectivity. A growing body of evidence links LTP and memory. This evidence is based, not only on the suggestive and numerous analogies between both phenomena but also on direct experiments demonstrating a relation between changes in synaptic efficacy and memory in different brain structures as well (Bergado et al., 1988; Matthies et al., 1986; Rioult-Pedotti et al., 1998; Rogan et al., 1997) (for a recent review on the subject see Martin \& Morris, 2002). It is plausible, therefore, that age-related disorders in synaptic plasticity might be functionally linked to memory impairment (Shapiro, 2001). These concepts are beginning to gain consideration for the effective prevention or treatment of such impairments (Rosenzweig, 1996).

In the present review we will focus our attention on describing how LTP is affected by aging, stressing new results linking memory and emotional disorders with the modulation of LTP in aged animals.

\section{THE GENERAL PROBLEM OF AGING}

Several hypotheses have been forwarded to explain the causes of aging. General theories emphasize the role of alterations in biological membranes, the attack of free radicals, calcium dysregulation, and (particularly in mammals) the negative effect of glucocorticoids and stress (Lynch, 1998b) Obviously, all the mentioned factors strongly interact with each other and might potentiate reciprocally, obscuring the possibility to develop a testable hypothesis regarding which might be the primary events in aging.
What appears clear is that aging is a process, and that aging is caused by the action of multiple factors. Aging affects all systems: Muscles weaken, bones become fragile, skin shrinks, arteries harden, hormones (particularly sex hormones) decay, immunity fades and memory fails.

\section{Aging and the nervous system}

The alterations in nervous system function as a consequence of aging are diverse. Aged persons (and animals) move different, sleep different, and show alterations in mood and memory. Neuron death and loss of afferents have been proposed as primary events leading to brain dysfunction (Morrison \& Hof, 1997; Ward et al., 1999). Although neuron death in specific brain regions is common in neurodegenerative diseases (Barili et al., 1998; Gerlach \& Riederer, 1996; Graeber et al., 1998; Landfield et al., 1992; Morrison \& Hof, 1997; West, 1993), the relative contribution of this factor to impairment in normal aging is a matter of debate (Rapp \& Gallagher, 1996; West, 1993). Non-neuronal alterations like an impaired blood flow (Ajmani et al., 2000) or glial dysfunction (Sykova, 2001) should also contribute to a generalized brain malfunction.

\section{Aging and memory impairment}

The decline in cognitive capacities in humans is one of the earliest, most dramatic, and generalized consequences of aging. Even in normal aged persons, memory dysfunctions limit intellectual abilities. In several pathological, age-related conditions, whether vascular or neuro-degenerative like Alzheimer's disease and other dementias, the impact of age on cognition is devastating. The literature showing memory alterations as a consequence of aging in rodents (Ando \& Ohashi, 1991; Kadar et al., 1990; Luparini et al., 2000; Ward et al., 1999; Ward et al., 1999), as well as in humans (Albert, 1997; Langley \& Madden, 2000; Soininen 
et al., 1994) and non-human primates (Bachevalier, Landis et al., 1991) is extensive. The cholinergic hypothesis of geriatric memory dysfunction (Bartus, 2000; Bartus et al., 1982) stresses the importance of the cholinergic afferents arising from the basal forebrain in memory functions (Baxter et al., 1999; Ikegami, 1994; Ikegami et al., 1992; Pedigo Jr, 1994; Russell, 1996; Shen et al., 1996; Smith et al., 1995) and has inspired some promising efforts in the search for effective treatments to overcome the agerelated cognitive impairments (Fernández et al., 1994; Fischer, 1994; Fischer et al., 1994; Flood et al., 1996; Garrone et al., 1998; Levin \& Torry, 1996; Scali et al., 1994; Sirvio, 1999; Smith et al., 1999; Vannucchi et al., 1997). Despite the intensive effort and literature supporting the cholinergic hypothesis, no clear picture has emerged on how acetylcholine might act to support memory processing.

When the methodological basis of animal learning models was established in the early years of the $20^{\text {th }}$ Century, it was immediately recognized that for an animal to learn something a strong motivation must be present. Much less attention has been paid, however, both clinically and experimentally, to the possible impact of dysfunctional emotional-motivational reactions on cognitive performance. Such neglect might appear surprising considering that aged related alterations in mood are widespread (Blazer, 1987) and often associated with neurodegenerative diseases (Harwood et al., 2000).

\section{AGING AND SYNAPTIC PLASTICITY}

\section{Mechanisms of plasticity}

Decades of intensive research have contributed to clarify the mechanisms involved in the induction, development, and maintenance of LTP. Although different forms of LTP seem to existaccording to the induction mechanisms involvedthe most common form requires the activation of
NMDA-type glutamate receptors (Bashir et al., 1991; Bashir et al., 1990; Collingridge, 1987; 1992). The NMDA ionophore allows the entrance of calcium to the postsynaptic region, an event that seems decisive to the strength and direction of the plastic modification. When the increase in $\mathrm{Ca}^{++}$is above certain values, an increase in synaptic efficacy (i.e., LTP) develops, but lower values could lead to the opposite, a reduction in synaptic efficacy (the so called Long-Term Depression, LTD) (Cormier et al., 2001; Foster \& Norris, 1997; Teyler et al., 1994). In LTP, $\mathrm{Ca}^{++}$activates protein kinases; whereas phosphatases are activated in LTD.

Several kinases have been proved to participate in the event cascade involved in LTP; among them, the $\mathrm{Ca}^{++}$-calmodulin dependent protein kinase II (PKII), the $\mathrm{Ca}^{++}$-phospholipid dependent protein kinase $\mathrm{C}$ (PKC), and the cyclic AMP dependent protein kinase A (PKA) (Abel et al., 1997; Colley et al., 1990; Fukunaga et al., 1996; Huang \& Kandel, 1994; Matthies \& Reymann, 1993; Reymann et al., 1988a; 1988b; Silva et al., 1992; Stevens et al., 1994). These enzymes can modify synaptic efficacy by acting pre- and post-synaptically. For example, PKII can increase the conductance of the AMPAglutamate receptors (Derkach et al., 1999), and consequently, increase the level of post-synaptic depolarization. But they can also act at distant regions, like the nucleus, regulating gene expression and protein synthesis (Nguyen \& Kandel, 1996; 1997; Pontzer et al., 1990).

The dependency of late phases of LTP (L-LTP, $>4 \mathrm{~h}$ ) on protein synthesis is well established (Frey et al., 1988; Krug et al., 1984; Otani \& Abraham, 1989). Such dependency has led to a multi-phase model of LTP, similar to that proposed for memory (Matthies et al., 1990). Yet, the identification of specific proteins required for LTP late maintenance has proven difficult. It seems that in a first step, proto-oncogenes are activated (Abraham et al., 1991; Bishop et al., 1994; Roberts et al., 1996), which can, in turn, activate structural genes; like 
those coding subunits of AMPA receptors (Desmond \& Weinberg, 1998).

The mechanism to guarantee LTP specificity after massive, non-specific protein synthesis requires the setting of a tag at the activated synapses, so that arriving proteins can be 'captured' only by those synapses that have been previously activated above a certain limit (Frey \& Morris, 1997; 1998).

Although the incorporation of new AMPA receptors might well subserve an increased synaptic efficacy in potentiated synapses, one can't help but wonder why so many other proteins are needed. One likely explanation is that really long, longlasting changes in synaptic efficacy are accompanied by morphological changes at the existing synapses - a possibility raised in early studies (Desmond \& Levy, 1986a; 1986b; 1988; Fifkova, 1985)-or the growth and establishment of new functional synaptic contacts. Electron microscope studies reveal signs of dendritic spine division and axonal sprouting days after induction of LTP by strong stimuli (Geinisman, 1993; Geinisman et al., 1989; Yuste \& Bonhoeffer, 2001).

Recent developments have shown that the plastic processes initiated by the activation of specific glutamatergic synapses can be modulated by synapses different from those previously involved in LTP induction (i.e., hetero-synaptically). This point is conceptually important because LTP has been considered a homosynaptic phenomenon, despite evidence indicating the need for heterosynaptic cooperation. An impaired LTP has been reported in animals bearing lesions of the fimbriafornix, the fiber system providing the hippocampus with cholinergic and aminergic fibers of subcortical origin (Bergado et al., 1996; Buzsáki \& Gage, 1989). Cooperation between the perforant pathway (mainly glutamatergic) and the septum (mainly non-glutamatergic) and the locus coeruleus (mainly noradrenergic) has also been documented (Harley \& Sara, 1992; Kitchigina et al., 1997;
Robinson \& Racine, 1982; 1986).

More recently, a group of studies has shown that the activation of the amygdala - a limbic structure related to emotion (Quirk et al., 1996) can influence the induction of LTP at the dentate gyrus (Akirav \& Richter-Levin, 1999; Ikegaya et al., 1995; Ikegaya et al., 1996). We have recently shown that the electrical stimulation of the amygdala also contributes to the maintenance of LTP, converting a short lasting early-LTP (E-LTP $<4 \mathrm{~h}$ ) into a lateLTP (L-LTP >4h) (Frey et al., 2001). Interestingly, the effect is protein-synthesis dependent and requires the activity of noradrenergic and cholinergic inputs. Lesioning of the fimbria-fornix, the main source of subcortical aminergic and cholinergic input to the hippocampal formation, impairs the reinforcing effect of the amygdala stimulation on LLTP (Abe et al., 1998; Jas et al., 2000). The activity of the amygdala also seems crucial for the socalled behavioral reinforcement of LTP. According to this paradigm, E-LTP can also be converted into an L-LTP by giving the animals a behavioral stimulus with a strong motivational content (i.e. drinking after 24-h water deprivation) shortly before, or after, inducing LTP using a weak tetanus (3x15 impulses at $200 \mathrm{~Hz}$ ) (Seidenbecheret al., 1995 ; 1997). We have recently obtained evidence that lesioning, or blocking the amygdala with lidocaine, abolishes the behavioral reinforcement of LTP (Almaguer et al., in press).

\section{AGE-RELATED CHANGES OF SYNAPTIC PLASTICITY}

\section{Developmental changes}

Like many other functions, synaptic plasticity presumably shows developmental changes during the early stages of postnatal life, followed by a period of relative stability in adulthood and then deteriorating slowly at older ages. 
LTP is difficult to induce before postnatal day 5. At P15 a level similar to adults can be reached (Teyler et al., 1989), but outlasting in time the duration of LTP in adults under similar induction paradigms (Bronzinoet al., 1994; 1995). Younger animals, on the other hand, seemed to be more prone to develop LTD (Dudek \& Bear, 1993; Wasling et al., 2002).

\section{Older animals show impaired synaptic plasticity}

Although earlier reports pointed to a reduced synaptic plasticity accompanying age-dependent memory impairment (see for example (Landfield et al., 1972), a demonstration of LTP deterioration with aging came from a series of elegant studies from Barnes and McNaughton (1985) (according to the references available to us). These authors demonstrated an impressive parallelism between the slower rate of development and the faster decay of memory and LTP among aged rats, compared with young controls (Barnes, 1979; Barnes \& McNaughton, 1985). This result was later confirmed by others (Bergado et al., 1997; de Toledo-Morrell \& Morrell, 1991; deToledo-Morrell et al., 1988; Diana, De Carolis et al., 1994; Geinisman, deToledo-Morrell et al., 1995) showing that behavioral, electrophysiological, and histological alterations were more profound in old rats with memory impairments than in similarly old animals without cognitive impairments. Later studies showed that aged rats were also more prone to develop LTD or to reverse LTP (depotentiation) by low frequency stimulation (Norris et al., 1996).

The former doesn't mean that aged rats are unable to develop LTP. When adequately stimulated, aged rats can reach an increase in synaptic efficacy, similar to that of young animals (Diana et al., 1994; Moore et al., 1993)-even those showing memory impairment-but the former seem to require stronger stimulation, and the decay rate is faster. This phenomenon has been attributed to an impaired "ability of aged rats' synapses to provide the sustained depolarization necessary to activate the LTP-induction cascade" (Rosenzweig et al., 1997).

\section{POSSIBLE MECHANISMS OF IMPAIRMENT}

\section{Impaired induction?}

Considering the importance of NMDA receptor activation for LTP induction, it seems plausible that any impairment in glutamatergic systems would have an impact on synaptic plasticity. In patients with Alzheimer's disease, neuropathology studies have shown that even in the early stages, the number of neurons in the entorhinal cortex is reduced (Braak \& Braak, 1992; Palmer, 2002). The evidence from aged animals is not so clear, at least regarding the total number of cells originating the perforant pathway (Gazzaley et al., 1997; Merrill et al., 2000; 2001). In the rat, however, there are indications of a reduced glutamatergic influence on the EPSP (Barnes et al., 1997; Billard et al., 1997). This decline might be related to a reduction in glutamate receptors in the cortex and in the hippocampus-particularly of the NMDA typethat have been repeatedly reported in rats (Kito et al., 1990; Liang \& Lu, 1992; Magnusson, 1998; Magnusson \& Cotman, 1993; Tamaru et al., 1991; Wenk et al., 1991) and probably associated with a change in the subunit composition (Clayton \& Browning, 2001; Clayton et al., 2002; Magnusson et al., 2002) and subtle subregional variations within hippocampal subfields (Wenk \& Barnes, 2000). The activity-dependent redistribution of NMDA receptors is also affected among aged rats (Clayton et al., 2002). Nevertheless, the basic mechanisms of NMDA-receptor induction mechanism for LTP seemed to be preserved (Barnes et al., 1996).

Aging seems to provoke a shift from NMDA- 
receptor calcium influx to Voltage Dependent Calcium Channels (VDCC) (Shankar et al., 1998), with the probable consequence that the increase in intracellular calcium will not reach the level required to activate $\mathrm{Ca}^{++}$-dependent kinases, but sufficient to activate phosphatases (Foster, 1999; Foster \& Norris, 1997). This situation would lead to the prediction that LTD and depotentiation are facilitated in aged rats, for which there is some experimental support (Norris et al., 1996). That blockade of VDCC attenuates this altered plasticity is in line with this hypothesis (Norris et al., 1998).

Other indications point to impaired regulation of protein kinases in aged animals. For PKII, a dysfunctional regulation of the alpha subunit has been reported in aged animals showing a decremental LTP (Davis et al., 2000), in contrast to those maintaining LTP beyond $3 \mathrm{~h}$. An age-related decrease of cortical plasticity was found in mutant mice lacking the $\alpha$ CaMKII subunit (Kirkwood et al., 1997). Similarly, a reduced PKC activity and its substrates has been experimentally documented in aged animals (Casoli et al., 1996; Chang et al., 1997; Mons et al., 2001; Okuma et al., 2000).

\section{Impaired maintenance?}

The temporal course of LTP in aged animals, particularly its faster decay, suggests an absent protein-synthesis dependent L-LTP. Several reports show alteration in protein synthesis and expression pattern or early genes among aged rats after LTP induction (Lanahan et al., 1997; Mullany \& Lynch, 1997). An impaired gene activation and protein synthesis might, in turn, affect the ability of axons and dendritic spines to divide, grow, and form new contacts that apparently are required for very longlasting LTP. In aged rats, electron micro-scopic studies have evidenced that this capacity might be quantitatively altered (Chang et al., 1991; Geinisman et al., 1992). In line with this evidence are findings showing that the expression of cell adhesion molecules required for axonal growth is impaired in aged rats (Ronn et al., 2000), indicating a deficient maintenance of LTP (Lynch \& Voss, 1994).

\section{Impaired heterosynaptic reinforcement?}

As mentioned previously, the activation of heterosynaptic afferents (i.e. behavioral or amygdala-induced reinforcement) to a neuronal population, in which an E-LTP has been induced through a mild tetanus, can prolong the duration of the plastic process, converting it into an L-LTP that is protein-synthesis dependent. This effect suggests that the activation of such afferents is able to induce the activity of molecular cascades, which complement the insufficiently activated cascade by the previous glutamatergic tetanus. Norepinephrine and acetylcholine have been implicated in those effects (Frey et al., 2001). Both transmitters have been shown to induce a slowly developing potentiation in in vitro studies, which might correlate with their effects on L-LTP. Norepinephrine and acetylcholine, when applied to slices obtained from young animals, induce a slowly developing potentiation (Segal \& Auerbach, 1997; Stanton \& Sarvey, 1987), which might represent an L-LTP. The effect of NE is protein synthesis dependent (Stanton \& Sarvey, 1985). Acetylcholine is responsible for theta rhythm in the hippocampus. The magnitude of LTP induced by tetani delivered at the positive theta peak was reduced in aged animals rats (Orr et al., 2001).

Recent results from our group provided the first evidence that such heterosynaptic reinforcing mechanisms might be deficient in aged rats, particularly among those animals showing memory deficits in a spatial task. Both behavioral- and amygdala-induced reinforcement are impaired, not only in cognitively deficient aged rats but also among aged rats showing no memory impairment in the Morris water maze (Almaguer et al., 2002; 
Bergado et al., 2001). Both noradrenergic and cholinergic systems in the brain are affected by aging (Baxter et al., 1999; Chouinard et al., 1995; Friedman \& Duckles, 1994; Isacson et al., 2002; Luine et al., 1990; Powers et al., 1988; Sherman \& Friedman, 1990; Stemmelin et al., 2000) and both can activate kinase systems involved in regulating protein synthesis (Bevilaqua et al., 1997; Stratton et al., 1988).

We assume that the deficient reinforcement of LTP by amygdala or by behavioral stimulation is caused by a reduction in noradrenergic and/or cholinergic afferents to the dentate gyrus, the brain area in which both studies were carried out.

The results of these studies provide a rationale, at the cellular level, for a possible functional link between two of the major consequences of aging: memory impairment and affective dystonia.

Additional factors might increase the negative impact of aging on synaptic plasticity. Chronic stress has been shown to lead to a disruption in LTP (Sapolsky, 1999) by the excessive production of glucocorticoids (Bodnoff et al., 1995; McEwen, 1994), to which aged rats seemed particularly sensitive. Also, inflammatory cytokines (Lynch, 1998a) have been shown to affect LTP in an agedependent manner.

Whereas a general agreement seems to have been reached on the relation between age-related impairments in plasticity and memory, some debate remains about which of the factors mentioned plays the major role in the degenerative process. We sustain the view that, most likely, all factors can be involved and interact cooperatively, leading to a continuously deteriorating plastic ability that causes, in turn, the decay in mnesic capacities.

\section{LINKS TO PATHOLOGY?}

Another important aspect to consider is whether alterations in synaptic plasticity might be also involved in memory losses in pathological forms of aging like Alzheimer's disease. New developments in animal models have provided indications that such a relation might exist.

The RNA for the amyloid precursor protein (APP), one of the key molecules in Alzheimer's pathogenesis, is upregulated after LTP induction in young rats, but not among aged rats regardless of whether they were cognitively impaired or not (Stephan et al., 2002). On the other hand, mutant mice lacking the APP gene, and in mice expressing the carboxy terminus of APP, released after proteolytic cleavage of the protein, showed an altered LTP maintenance (Nalbantoglu et al., 1997; Seabrook, Smith et al., 1999). Moreover, mice overexpressing mutant forms of human APP developed not only the typical histopathology of Alzheimer's but also an altered plasticity (Chapman et al., 1999; Larson et al., 1999) (see however (Fitzjohn et al., 2001).

\section{AN IMPACT ON THERAPEUTICS?}

The studies on the alterations of synaptic plasticity in aging have also provided some results of potential therapeutic implications.

General factors like caloric restriction (EcklesSmith et al., 2000) or dietary supplement with antioxidants (vitamin E or lipoic acid) (Murray \& Lynch, 1998; McGahon et al., 1999) reverse ageddependent alterations in LTP, and improve glutamatergic transmission in the dentate gyrus. The use of calcium regulators like nimodipine or nifedipine has shown beneficial effects on LTP among aged rats (De Jong et al., 1992; Norris et al., 1998), and cholinergic agonists have improved declining LTP in aged rats (Fujii \& Sumikawa, 2001).

Trophic factors are among the greatest hopes of restorative neurology in the last decades. Some have shown a direct effect on synaptic plasticity. Early reports suggested an action for epidermal 
growth factor (EGF) and fibroblast growth factor (FGF), but not nerve growth factors (NGF), promoting LTP in normal and lesioned rats (Abe et al., 1992; Ishiyama et al., 1991; Terlau \& Seifert, 1990). More recently, the results of in vitro and in vivo studies have shown that brain-derived neurotrophic factor (BDNF) or neurotrophin-3 (NT-3), but again not NGF, are able to induce an LTP-like plastic development in the hippocampus (Chen et al., 1999; Kang \& Schuman, 1995a; 1995b; 1996; Kovalchuk et al., 2002; Lu \& Chow, 1999), thus re-opening the issue for a potential use of BDNF for the treatment of age-related memory impairments. Although NGF cannot by itself induce LTP, chronic treatment with NGF restores the ability of aged, memory-deficient rats to develop LTP (Bergado et al., 1997; Bergado et al., 1998), a result that correlates with behavioral studies showing an improvement in memory function after similar treatment (Fischer et al., 1994). We interpret this effect as mediated by the protective and restorative function of NGF on the basal forebrain cholinergic projection to the hippocampus and cortex. Similar results have been reported after the transplantation of septal fetal neurons to aged rats, or in rats with lesion of the septo-hippocampal projection (Bergado et al., 1997; Björklund \& Stenevi, 1977; Fernández et al., 1994; Leanza et al., 1998) Although neurotrophic administration to the brain is technically difficult, an intensive search for new strategies could bring some promising results to this important field.

\section{CONCLUSIONS}

The accumulated evidence seems reasonably sufficient to postulate the existence of a functional link between the age-dependent impairment in synaptic plasticity and the deterioration of memory function. The knowledge about the mechanisms of LTP can lead not only to a better understanding of the causality of memory decline with age but also to the development of new therapeutic strategies for treating it. Several lines of evidence also point to an impaired relation, at the cellular level, between affective and cognitive processes. Any progress in these important topics can represent a substantial contribution to reach the goal of successful aging, so that the years gained for life can also be an enjoyable period of existence.

\section{REFERENCES}

Abe K, Ishiyama J, Saito H. 1992. Effects of epidermal growth factor and basic fibroblast growth factor on generation of long-term potentiation in the dentate gyrus of fimbria-fornix-lesioned rats. Brain Res 593: 335-338.

Abe K, Noguchi K, Saito H. 1998. Medial amygdalainduced spike potentiation in the rat dentate gyrus is dependent on N-methyl-D-aspartate receptors and subcortical afferents. Neurosci Lett 246: 8588.

Abel T, Nguyen PV, Barad M, Deuel TAS, Kandel ER. 1997. Genetic demonstration of a role for PKA in the late phase of LTP and in hippocampus-based long-term memory. Cell 88: 615-626.

Abraham WC, Dragunow M, Tate WP. 1991. The role of immediate early genes in the stabilization of long-term potentiation. Mol Neurobiol 5: 297314.

Ajmani RS, Metter EJ, Jaykumar R, Ingram DK, Spangler EL, et al. 2000. Hemodynamic changes during aging associated with cerebral blood flow and impaired cognitive function. Neurobiol Aging 21: 257-269.

Akirav I, Richter-Levin G. 1999. Priming stimulation in the basolateral amygdala modulates synaptic plasticity in the rat dentate gyrus. Neurosci Lett 270: 83-86.

Albert MS. The ageing brain: normal and abnormal memory. 1997. Philos Trans R Soc Lond B Biol Sci 352: 1703-1709.

Almaguer $\mathrm{W}$, Estupiñán $\mathrm{B}$, Frey $\mathrm{JU}$, Bergado JA. 2002. Aging impairs amygdala-hippocampus interactions involved in hippocampal LTP. Neurobiol 
Aging 23: 319-324.

Almaguer-Melian W, Martinez-Marti L, Frey JU, Bergado JA. In press. The amygdala is part of the behavioral reinforcement system required for LTP in rat hippocampus. Neuroscience.

Ando S, Ohashi Y. 1991. Longitudinal study on agerelated changes of working and reference memory in the rat. Neurosci Lett 128: 17-20.

Bachevalier J, Landis LS, Walker LC, Brickson M, Mishkin M, Price DL, Cork LC. 1991. Aged monkeys exhibit behavioral deficits indicative of widespread cerebral dysfunction. Neurobiol Aging 12: 99-111.

Barili P, De Carolis G, Zaccheo D, Amenta F. 1998. Sensitivity to ageing of the limbic dopaminergic system: a review. Mech Ageing Dev 106: 57-92.

Barnes CA. 1979. Memory deficits associated with senes-cence: A neurophysiological and behavioural study in the rat. J Comp Physiol Psychol 93: 74-104.

Barnes CA, McNaughton BL. 1985. An age comparison of the rates of acquisition and forgetting. Behav Neurosci 99: 1040-1048.

Barnes CA, Rao G, McNaughton BL. 1996. Functional integrity of NMDA-dependent LTP induction mechanisms across the lifespan of F-344 rats. Learn Mem 3: 124-137.

Barnes CA, Rao G, Shen J. 1997. Age-related decrease in the N-methyl-D-aspartate ${ }_{\mathrm{R}}$-mediated excitatory postsynaptic potential in hippocampal region CA1. Neurobiol Aging 18: 445-452.

Bartus RT. 2000. On neurodegenerative diseases, models, and treatment strategies: lessons learned and lessons forgotten a generation following the cholinergic hypothesis. Exp Neurol 163: 495-529.

Bartus RT, Dean III RL, Beer B, Lippa AS. 1982. The cholinergic hypothesis geriatric memory dysfunction. Science 217: 408-417.

Bashir ZI, Alford S, Davies SN, Randall AD, Collingridge GL. 1991. Long-term potentiation of NMDA receptor-mediated synaptic transmission in the hippocampus. Nature 349: 156-158.

Bashir ZI, Tam B, Collingridge GL. 1990. Activation of the glycine site in the NMDA receptor is necessary for the induction of LTP. Neurosci Lett 108: 261-266.

Baxter MG, Frick KM, Price DL, Breckler SJ, Markowska AL, Gorman LK. 1999. Presynaptic markers of cholinergic function in the rat brain: relationship with age and cognitive status.
Neuroscience 89: 771-779.

Bergado JA, Almaguer W, Ravelo J, Rosillo JC, Frey JU. 2001. Behavioral reinforcement of long-term potentiation is impaired in aged rats with cognitive deficiencies. Neuroscience 108: 1-5.

Bergado JA, Fernández CI, Gómez-Soria A, González O. 1997. Chronic intraventricular infusion with NGF improves LTP in old cognitively-impaired rats. Brain Res 770: 1-9.

Bergado JA, Gómez-Soria A, Cruz R, Fernandez CI. 1998. Nerve growth factor improves evoked potentials and long-term potentiation in the dentate gyrus of presenile rats. Eur J Pharmacol 345: 181-184.

Bergado JA, Krug M, R:uthrich H, Matthies H. 1988. Orotate improves memory and enhances synaptic long-term potentiation in active avoidance behaviour in rats with perforant path stimulation as the conditioned stimulus. Eur J Pharmacol 157: 155-163.

Bergado JA, Moreno H, Nuñez N. 1996. Fimbriafornix lesion impairs long-term potentiation in the dentate gyrus of the rat. Biol Res 29: 197-202.

Bergado JA, Moreno H, Soto J, Castellano O, Castillo L. 1997. Septal fetal tissue transplants restore long-term potentiation in the dentate gyrus of fimbria-formix-lesioned rats. J Neural Transplant Plast 6: 31-40.

Bevilaqua L, Ardenghi P, Schröder N, Bromberg E, Schmitz PK, Schaeffer E, et al. 1997. Drugs acting upon the cyclic adenosine monophosphate protein kinase A signalling pathway modulate memory consolidation when given late after training into rat hippocampus but not amygdala. Behav Pharmacol 8: 331-338.

Billard JM, Jouvenceau A, Lamour Y, Dutar P. 1997; NMDA receptor activation in the aged rat: electrophysiological investigations in the CA1 area of the hippocampal slice ex vivo. Neurobiol Aging 18: 535-542.

Bishop JM, Capobianco AJ, Doyle HJ, Finney RE, McMahon M, Robbins SM, et al. 1994. Protooncogenes and plasticity in cell signaling. Cold Spring Harbor Symp Quant Biol 59: 165-172.

Björklund A, Stenevi U. 1977. Reformation of the severed septohippocampal cholinergic pathway in the adult rat by transplanted septal neurons. Cell Tissue Res 185: 289-302.

Blazer D. 1989. Depression in the elderly. N Engl J Med. 320: 164-166. 
Bliss TV, Gardner-Medwin AR. 1973. Long-lasting potentiation of synaptic transmission in the dentate area of the unanaestetized rabbit following stimulation of the perforant path. J Physiol (Lond) 232: 357-374.

Bliss TV, Lomo T. 1973. Long-lasting potentiation of synaptic transmission in the dentate area of the anaesthetized rabbit following stimulation of the perforant path. J Physiol (Lond) 232: 331-356.

Bodnoff SR, Humphreys AG, Lehman JC, Diamond DM, Rose GM, Meaney MJ. 1995. Enduring effects of chronic corticosterone treatment on spatial learning, synaptic plasticity, and hippocampal neuropathology in young and midaged rats. J Neurosci 15: 61-69.

Braak H, Braak E. 1992. The human entorhinal cortex: normal morphology and lamina-specific pathology in various diseases. Neurosci Res 15: 6-31.

Bronzino JD, Abu-Hasaballah K, Austin-LaFrance RJ, Morgane PJ. 1994. Maturation of long-term potentiation in the hippocampal dentate gyrus of the freely moving rat. Hippocampus $4: 439-446$.

Bronzino JD, Abu-Hasaballah K, Austin-LaFrance RJ, Morgane PJ. 1995. Quantitative analysis of longterm potentiation in the hippocampal dentate gyrus of the freely-moving 15-day-old rat. Brain Res Bull 36: 321-324.

Buzsáki G, Gage FH. 1989. Absence of long-term potentiation in the subcortically deafferented dentate gyrus. Brain Res 484: 94-101.

Casoli T, Spagna C, Fattoretti P, Gesuita R, BertoniFreddari C. 1996. Neuronal plasticity in aging: a quantitative immunohistochemical study of GAP43 distribution in discrete regions of the rat brain. Brain Res 714: 111-117.

Chang JW, Schumacher E, Coulter PM, Vinters HV, Watson JB. 1997. Dendritic translocation of RC3/ neurogranin mRNA in normal aging, Alzheimer disease and fronto-temporal dementia. J Neuropathol Exp Neurol 56: 1105-1118.

Chang PL, Isaacs KR, Greenough WT. 1991. Synapse formation occurs in association with the induction of long-term potentiation in two-year-old rat hippo-campus in vitro. Neurobiol Aging 12: $517-$ 522.

Chapman PF, White GL, Jones MW, Cooper-Blacketer D, Marshall VJ, Irizarry M, et al. 1999. Impaired synaptic plasticity and learning in aged amyloid precursor protein transgenic mice. Nat Neurosci 2: 271-276.
Chen G, Kolbeck R, Barde YA, Bonhoeffer T, Kossel A. 1999. Relative contribution of endogenous neurotrophins in hippocampal long-term potentiation. J Neurosci 19: 7983-7990.

Chouinard ML, Gallagher M, Yasuda RP, Wolfe BB, McKinney M. 1995. Hippocampal muscarinic receptor function in spatial learning- impaired aged rats. Neurobiol Aging 16: 955-963.

Clayton DA, Browning MD. 2001. Deficits in the expression of the NR2B subunit in the hippocampus of aged Fisher 344 rats. Neurobiol Aging 22: $165-168$.

Clayton DA, Grosshans DR, Browning MD. 2002. Aging and surface expression of hippocampal NMDA receptors. J Biol Chem 277: 1436714369.

Clayton DA, Mesches MH, Alvarez E, Bickford PC, Browning MD. 2002. A hippocampal NR2B deficit can mimic age-related changes in long-term potentiation and spatial learning in the Fischer 344 rat. J Neurosci 22: 3628-3637.

Colley PA, Sheu FS, Routtenberg A. 1990. Inhibition of protein kinase $\mathrm{C}$ blocks two components of LTP persistence, leaving initial potentiation intact. J Neurosci 10: 3353-3360.

Collingridge G. 1987. The role of NMDA receptors in learning and memory. Nature 330: 604-605.

Collingridge GL. 1992. The mechanism of induction of NMDA receptor-dependent long-term potentiation in the hippocampus. Exp Physiol 77: 771-797.

Cormier RJ, Greenwood AC, Connor JA. 2001. Bidirectional synaptic plasticity correlated with the magnitude of dendritic calcium transients above a threshold. J Neurophysiol 85: 399-406.

Davis S, Salin H, Helme-Guizon A, Dumas S, Stephan A, et al. 2000. Dysfunctional regulation of alphaCaMKII and syntaxin 1B transcription after induction of LTP in the aged rat. Eur J Neurosci 12: 3276-3282.

De Jong GI, Buwalda B, Schuurman T, Luiten PG. 1992; Synaptic plasticity in the dentate gyrus of aged rats is altered after chronic nimodipine application. Brain Res 596: 345-348.

Derkach V, Barria A, Soderling TR. 1999. $\mathrm{Ca}^{2+} /$ calmodulin-kinase II enhances channel conductance of alpha-amino-3- hydroxy-5-methyl4-isoxazole-propionate type glutamate receptors. Proc Natl Acad Sci USA 96: 3269-3274.

Desmond NL, Levy WB. 1986a. Changes in the numerical density of synaptic contacts with long- 
term potentiation in the hippocampal dentate gyrus. J Comp Neurol 253: 466-475.

Desmond NL, Levy WB. 1986b. Changes in the postsynaptic density with long-term potentiation in the dentate gyrus. J Comp Neurol 253: 476-482.

Desmond NL, Levy WB. 1988. Synaptic interface surface area increases with long-term potentiation in the hippocampal dentate gyrus. Brain Res 453: 308-314.

Desmond NL, Weinberg RJ. 1998. Enhanced expression of AMPA receptor protein at perforated axospinous synapses. Neuroreport 9: 857-860.

deToledo-Morrell L, Geinisman Y, Morrell F. 1988 Age-dependent alterations in hippocampal synaptic plasticity: relation to memory disorders. Neurobiol Aging 9: 581-590.

deToledo-Morrell L, Morrell F. 1991. Age-related alterations in long-term potentiation and susceptibility to kindling. In: Morrell F, ed, Kindling and synaptic plasticity: the legacy of Graham Goddard. Boston, Massachusetts, USA: Birkhaüser; 160 175.

Diana G, Scotti de Carolis A, Frank C, Domenici MR, Sagratella S. 1994. Selective reduction of hippocampal dentate frequency potentiation in aged rats with impaired place learning. Brain Res Bull 35: 107-111.

Diana G, Domenici MR, Loizzo A, Scotti de Carolis A, Sagratella S. 1994. Age and strain differences in rat place learning and hippocampal dentate gyrus frequency-potentiation. Neurosci Lett 171: $113-116$

Dudek SM, Bear MF. 1993. Bidirectional long-term modification of synaptic effectiveness in the adult and immature hippocampus. J Neurosci 13: 29102918.

Eckles-Smith K, Clayton D, Bickford P, Browning MD. 2000. Caloric restriction prevents age-related deficits in LTP and in NMDA receptor expression. Brain Res Mol Brain Res 78: 154-162.

Fernandez CI, Bergado J, De La Quetara K, Nunez N, Castellanos O, Gonzalez O, et al. 1994. Brain aging and neurotransplantation. II. Effects of septal cell suspension grafts to hippocampus of aged rodents on learning and memory impairments. Arch Gerontol Geriatr 4 (Suppl): 59-65.

Fifkova E. 1985. A possible mechanism of morphometric changes in dendritic spines induced by stimulation. Cell Mol Neurobiol 5: 47-63.

Fischer W. 1994. Nerve growth factor reverses spatial memory impairments in aged rats. Neurochem Int 25: 47-52.

Fischer W, Sirevaag A, Wiegand SJ, Lindsay RM, Bjorklund A. 1994. Reversal of spatial memory impairments in aged rats by nerve growth factor and neurotrophins 3 and $4 / 5$ but not by brainderived neurotrophic factor. Proc Natl Acad Sci USA 91: 8607-8611.

Fitzjohn SM, Morton RA, Kuenzi F, Rosahl TW, Shearman M, Lewis H, et al. 2001. Age-related impairment of synaptic transmission but normal long-term potentiation in transgenic mice that overexpress the human APP695SWE mutant form of amyloid precursor protein. J Neurosci 21: 4691-4698.

Flood JF, Harris FJ, Morley JE. 1996. Age-related changes in hippocampal drug facilitation of memory processing in SAMP8 mice. Neurobiol Aging 17: 15-24.

Foster TC. 1999. Involvement of hippocampal synaptic plasticity in age-related memory decline. Brain Res Brain Res Rev 30: 236-249.

Foster TC, Norris CM. 1997. Age-associated changes in $\mathrm{Ca} 2+$-dependent processes: relation to hippocampal synaptic plasticity. Hippocampus 7: 602612.

Frey S, Bergado JA, Seidenbecher T, Pape HC, Frey JU. 2001. Reinforcement of early-LTP in dentate gyrus by stimulation of the basolateral amygdala: Hetero-synaptic induction of late-LTP. J Neurosci 21: 3697-3603.

Frey U, Krug M, Reymann KG, Matthies H. 1988. Anisomycin, an inhibitor of protein synthesis, blocks late phases of LTP phenomena in the hippocampal CA1 region in vitro. Brain Res 452: 57-65.

Frey U, Morris RG. 1997. Synaptic tagging and longterm potentiation. Nature 385(6616): 533-536.

Frey U, Morris RG. 1998. Synaptic tagging: implications for late maintenance of hippocampal longterm potentiation. Trends Neurosci 21: 181-188.

Friedman DJ, Duckles SP. 1994. Influence of age on control of norepinephrine release: $\mathrm{Ca} 2+$ channels and dopamine D2 receptors. Eur J Pharmacol 252: 1-9.

Fujii S, Sumikawa K. 2001. Acute and chronic nicotine exposure reverse age-related declines in the induction of long-term potentiation in the rat 
hippocampus. Brain Res 894: 347-353.

Fukunaga K, Muller D, Miyamoto E. 1996. CaM kinase II in long-term potentiation. Neurochem Int 28: 343-358.

Garrone B, Luparini MR, Tolu L, Landolfi C, Milanese C. 1998. Effect of the subchronic treatment with the acetylcholinesterase inhibitor heptastigmine on central cholinergic transmissin and memory impair- ment in aged rats. Neurosci Lett 245: 53-57.

Gazzaley AH, Thakker MM, Hof PR, Morrison JH. 1997. Preserved number of entorhinal cortex layer II neurons in aged macaque monkeys. Neurobiol Aging 18: 549-553.

Geinisman Y. 1993. Perforated axospinous synapses with multiple, completely partitioned transmission zones: Probable structural intermediates in synaptic plasticity. Hippocampus 3: 417-434.

Geinisman Y, deToledo-Morrell L, Morrell F, Heller RE. 1995. Hippocampal markers of age-related memory dysfunction: behavioral, electrophysiological and morphological perspectives. Prog Neurobiol 45: 223-252.

Geinisman Y, Morrell F, de Toledo-Morrell L. 1989. Perforated synapses on double-headed dendritic spines: a possible structural substrate of synaptic plasticity. Brain Res 480: 326-329.

Geinisman Y, Toledo-Morrell L, Morrell F, Persina IS, Rossi M. 1992. Structural synaptic plasticity associated with the induction of long-term potentiation is preserved in the dentate gyrus of aged rats. Hippocampus 2: 445-456.

Gerlach M, Riederer P. 1996. Animal models of Parkinson's disease: An empirical comparison with the phenomenology of the disease in man. J Neural Transm 103: 987-1041.

Graeber MB, Grasbon-Frodl E, Eitzen UV, Kösel S. 1998. Neurodegeneration and aging: Role of the second genome. J Neurosci Res 52: 1-6.

Harley CW, Sara SJ. 1992. Locus coeruleus bursts induced by glutamate trigger delayed perforant path spike amplitude potentiation in the dentate gyrus. Exp Brain Res 89: 581-587.

Harwood DG, Barker WW, Ownby RL, Duara R. 2000. Relationship of behavioral and psychological symptoms to cognitive impairment and functional status in Alzheimer's disease. Int $\mathrm{J}$ Geriatr Psychiatry 15: 393-400.

Huang YY, Kandel ER. 1994. Recruitment of longlasting and protein kinase A-dependent long-term potentiation in the CA1 region of hippocampus requires repeated tetanization. Learn Mem 1: 7482.

Ikegami S. 1994. Behavioral impairment in radial-arm maze learning and acetylcholine content of the hippocampus and cerebral cortex in aged mice. Behav Brain Res 65: 103-111.

Ikegami S, Shumiya S, Kawamura H. 1992. Agerelated changes in radial-arm maze learning and basal forebrain cholinergic systems in senescence accelerated mice (SAM). Behav Brain Res 51: 1522.

Ikegaya Y, Saito H, Abe K. 1995. High-frequency stimulation of the basolateral amygdala facilitates the induction of long-term potentiation in the dentate gyrus in vivo. Neurosci Res 22: 203-207.

Ikegaya Y, Saito H, Abe K. 1996. The basomedial and basolateral amygdaloid nuclei contribute to the induction of long-term potentiation in the dentate gyrus in vivo. Eur J Neurosci 8: 1833-1839.

Isacson $\mathrm{O}$, Seo $\mathrm{H}$, Lin L, Albeck D, Granholm AC. 2002. Alzheimer's disease and Down's syndrome: roles of APP, trophic factors and ACh. Trends Neurosci 25: 79-84.

Ishiyama J, Saito H, Abe K. 1991. Epidermal growth factor and basic fibroblast growth factor promote the generation of long-term potentiation in the dentate gyrus of anaesthetized rats. Neurosci Res 12: 403-411.

Jas J, Almaguer W, Frey JU, Bergado J. 2000. Lesioning the fimbria-fornix impairs basolateral amygdala induced reinforcement of LTP in the dentate gyrus. Brain Res 861: 186-189.

Kadar T, Silbermann M, Brandeis R, Levy A. 1990. Age-related structural changes in the rat hippocampus: correlation with working memory deficiency. Brain Res 512: 113-120.

Kang H, Schuman EM. 1995a. Long-lasting neurotrophin-induced enhancement of synaptic transmission in the adult hippocampus. Science 267 (5204): 1658-1662.

Kang HJ, Schuman EM. 1995b. Neurotrophin-induced modulation of synaptic transmission in the adult hippocampus. J Physiol Paris 89: 11-22.

Kang HJ, Schuman EM. 1996. A requirement for local protein synthesis in neurotrophin-induced hippocampal synaptic plasticity. Science 273(5280): 1402-1406.

Kirkwood A, Silva A, Bear MF. 1997. Age-dependent decrease of synaptic plasticity in the neocortex of 
alphaCaMKII mutant mice. Proc Natl Acad Sci USA. 94: 3380-3383.

Kitchigina V, Vankov A, Harley C, Sara SJ. 1997. Novelty-elicited, noradrenaline-dependent enhance- ment of excitability in the dentate gyrus. Eur J Neurosci 9: 41-47.

Kito S, Miyoshi R, Nomoto T. 1990. Influence of age on NMDA receptor complex in rat brain studied by in vitro autoradiography. $\mathrm{J}$ Histochem Cytochem 38: 1725-1731.

Kovalchuk Y, Hanse E, Kafitz KW, Konnerth A. 2002. Postsynaptic induction of BDNF-mediated longterm potentiation. Science 295(5560): 1729-1734.

Krug M, Lossner B, Ott T. 1984. Anisomycin blocks the late phase of long-term potentiation in the dentate gyrus of freely moving rats. Brain Res Bull 13: 39-42.

Lanahan A, Lyford G, Stevenson GS, Worley PF, Barnes CA. 1997. Selective alteration of long-term potentiation-induced transcriptional response in hippocampus of aged, memory-impaired rats. J Neurosci 17: 2876-2885.

Landfield PW, McGaugh JL, Tusa RJ. 1972. Theta rhythm: a temporal correlate of memory storage processes in the rat. Science 175: 87-89.

Landfield PW, Thibault O, Mazzanti ML, Porter NM, Kerr DS. 1992. Mechanisms of neuronal death in brain aging and Alzheimer's disease: Role of endocrine-mediated calcium dyshomeostasis. J Neurobiol 23: 1247-1260.

Langley LK, Madden DJ. 2000. Functional neuroimaging of memory: implications for cognitive aging. Microsc Res Tech 51: 75-84.

Larson J, Lynch G, Games D, Seubert P. 1999. Alterations in synaptic transmission and long-term potentiation in hippocampal slices from young and aged PDAPP mice. Brain Res 840: 23-35.

Leanza G, Martinez-Serrano A, Bjorklund A. 1998. Amelioration of spatial navigation and short-term memory deficits by grafts of foetal basal forebrain tissue placed into the hippocampus and cortex of rats with selective cholinergic lesions. Eur $\mathbf{J}$ Neurosci 10: 2353-2370.

Levin ED, Torry D. 1996. Acute and chronic nicotine effects on working memory in aged rats. Psychopharmacology (Berl) 123: 88-97.

Liang F, Lu B. 1992. Changes in excitatory amino acids and $\mathrm{N}$-methyl-D-aspartate receptors in the brain in aged mice. Zhonghua Yi Xue Za Zhi 72: 33-35, 64. Chinese.
Lu B, Chow A. 1999. Neurotrophins and hippocampal synaptic transmission and plasticity. J Neurosci Res 58: 76-87.

Luine V, Bowling D, Hearns M. 1990. Spatial memory deficits in aged rats: contributions of monoaminergic systems. Brain Res 537: 271-278.

Luparini MR, Del Vecchio A, Barillari G, Magnani M, Prosdocimi M. 2000. Cognitive impairment in old rats: a comparison of object displacement, object recognition and water maze. Aging (Milano ) 12 264-273.

Lynch MA. 1998a. Age-related impairment in longterm potentiation in hippocampus: a role for the cytokine, interleukin-1 beta?. Prog Neurobiol 56: 571-589.

Lynch MA. 1998b. Analysis of the mechanisms underlying the age-related impairment in long-term potentiation in the rat. Rev Neurosci 1998b. 9: 169-201.

Lynch MA, Voss KL. 1994. Membrane arachidonic acid concentration correlates with age and induction of long-term potentiation in the dentate gyrus in the rat. Eur J Neurosci 6: 1008-1014.

Magnusson KR. 1998. Aging of glutamate receptors: correlations between binding and spatial memory performance in mice. Mech Ageing Dev 104: 227-248.

Magnusson KR, Cotman CW. 1993. Effects of aging on NMDA and MK801 binding sites in mice. Brain Res 604: 334-37.

Magnusson KR, Nelson SE, Young AB. 2002. Agerelated changes in the protein expression of subunits of the NMDA receptor. Brain Res Mol Brain Res 99: 40-45.

Martin SJ, Morris RG. 2002. New life in an old idea: the synaptic plasticity and memory hypothesis revisited. Hippocampus 12: 609-636.

Matthies H. 1998. Neuronale Grundlagen der Gedächtnisbildung. Enzyklopädie der Psychologie $15-42$.

Matthies H, Frey U, Reymann K, Krug M, Jork R, Schroeder H. Different mechanisms and multiple stages of LTP. Adv Exp Med Biol 1990. 268: 359368.

Matthies H, Reymann KG. 1993. Protein kinase A inhibitors prevent the maintenance of hippocampal long-term potentiation. Neuroreport 4: 712-714.

Matthies H, Ruethrich H, Ott T, Matthies HK, Matthies R. 1986. Low frequency perforant path stimulation as a conditioned stimulus demonstrates 
correlations between long-term synaptic potentiation and learning. Physiol Behav 36: 811821.

McEwen BS. 1994. Corticosteroids and hippocampal plasticity. Ann NY Acad Sci 746: 134-142; discussion 142-144, 178-179.

McGahon BM, Martin DS, Horrobin DF, Lynch MA. 1999. Age-related changes in LTP and antioxidant defenses are reversed by an alpha-lipoic acidenriched diet. Neurobiol Aging 20: 655-664.

Medina JF, Christopher Repa J, Mauk MD, LeDoux JE. 2002. Parallels between cerebellum- and amygdala- dependent conditioning. Nat Rev Neurosci 3: 122-131.

Merrill DA, Chiba AA, Tuszynski MH. 2001. Conservation of neuronal number and size in the entorhinal cortex of behaviorally characterized aged rats. J Comp Neurol 438: 445-456.

Merrill DA, Roberts JA, Tuszynski MH. 2000. Conservation of neuron number and size in entorhinal cortex layers II, III, and V/VI of aged primates. J Comp Neurol 422: 396-401.

Milner B, Squire LR, Kandel ER. 1998. Cognitive neuroscience and the study of memory. Neuron 20: 445-468.

Mons N, Enderlin V, Jaffard R, Higueret P. 2001. Selective age-related changes in the PKCsensitive, calmodulin-binding protein, neurogranin, in the mouse brain. J Neurochem 79: 859-867.

Moore CI, Browning MD, Rose GM. 1993. Hippocampal plasticity induced by primed burst, but not long-term potentiation, stimulation is impaired in area CA1 of aged Fischer 344 rats. Hippocampus 3: 57-66.

Morrison JH, Hof PR. 1997. Life and death of neurons in the aging brain. Science 278(5337): 412-419.

Mullany P, Lynch MA. 1997. Changes in protein synthesis and synthesis of the synaptic vesicle protein, synaptophysin, in entorhinal cortex following induction of long-term potentiation in dentate gyrus: an age- related study in the rat. Neuropharmacology 36: 973-980.

Murray CA, Lynch MA. 1998. Dietary supplementation with vitamin $\mathrm{E}$ reverses the agerelated deficit in long term potentiation in dentate gyrus. J Biol Chem 273: 12161-12168.

Nalbantoglu J, Tirado-Santiago G, Lahsaïni A, Poirier J, Goncalves O, Verge A, et al. 1997. Impaired learning and LTP in mice expressing the carboxy terminus of the Alzheimer amyloid precursor protein. Nature 387(6632): 500-505.

Nguyen PV, Kandel ER. 1996. A macromolecular synthesis-dependent late phase of long-term potentiation requiring cAMP in the medial perforant pathway of rat hippocampal slices. J Neurosci 16: 3189-3198.

Nguyen PV, Kandel ER. 1997. Brief theta-burst stimulation induces a transcription-dependent late phase of LTP requiring CAMP in area CAl of the mouse hippocampus. Learn Mem 4: 230-243.

Norris CM, Halpain S, Foster TC. 1998. Reversal of age-related alterations in synaptic plasticity by blockade of L-type Ca2+ channels. J Neurosci 18: 3171-3179.

Norris CM, Korol DL, Foster TC. 1996. Increased susceptibility to induction of long-term depression and long-term potentiation reversal during aging. $J$ Neurosci 16: 5382-5392.

Okuma Y, Murayama T, Tha KK, Yamada C, Hosokawa M, Ishikawa A, et al. 2000. Learning deficiency and alterations in acetylcholine receptors and protein kinase $\mathrm{C}$ in the brain of senescence-accelerated mouse (SAM)-P10. Mech Ageing Dev 114: 191-199.

Orr G, Rao G, Houston FP, McNaughton BL, Barnes CA. Hippocampal synaptic plasticity is modulated by theta rhythm in the fascia dentata of adult and aged freely behaving rats. Hippocampus 2001. 11: 647-654.

Otani S, Abraham WC. 1989. Inhibition of protein synthesis in the dentate gyrus, but not the entorhinal cortex, blocks maintenance of long-term potentiation in rats. Neurosci Lett 106: 175-180.

Palmer AM. 2002. Pharmacotherapy for Alzheimer's disease: progress and prospects. Trends Pharmacol Sci 23: 426-433.

Pedigo NW Jr. 1994. Neurotransmitter receptor plasticity in aging. Life Sci 55: 1985-1991.

Pontzer NJ, Chandler LJ, Stevens BR, Crews FT. 1990. Receptors, phosphoinositol hydrolysis and plasticity of nerve cells. Prog Brain Res 86: 221225.

Powers RE, Struble RG, Casanova MF, O'Connor DT, Kitt CA, Price DL. 1988. Innervation of human hippocampus by noradrenergic systems: normal anatomy and structural abnormalities in aging and in Alzheimer's disease. Neuroscience 25: 401417.

Quirk GJ, Armony JL, Repa JC, Li XF, LeDoux JE. 
1996. Emotional memory: A search for sites of plasticity. Cold Spring Harbor Symp Quant Biol 61: 247-257.

Rapp PR, Gallagher M. 1996. Preserved neuron number in the hippocampus of aged rats with spatial learning deficits. Proc Natl Acad Sci USA 93: 9926-9930.

Reymann KG, Brödemann R, Kase H, Matthies H. 1988. Inhibitors of calmodulin and protein kinase C block different phases of hippocampal longterm potentiation. Brain Res 461: 388-392.

Reymann KG, Frey U, Jork R, Matthies H. 1988. Polymyxin B, an inhibitor of protein kinase $C$, prevents the maintenance of synaptic long-term potentiation in hippocampal CA1 neurons. Brain Res 440: 305-314.

Rioult-Pedotti MS, Friedman D, Hess G, Donoghue JP. 1998. Strengthening of horizontal cortical connections following skill learning. Nat Neurosci 1: 230-234.

Roberts LA, Higgins MJ, O'Shaughnessy CT, Stone TW, Morris BJ. 1996. Changes in hippocampal gene expression associated with the induction of long-term potentiation. Mol Brain Res 42: 123127.

Robinson GB, Racine RJ. 1982. Heterosynaptic interactions between septal and entorhinal inputs to the dentate gyrus: long-term potentiation effects. Brain Res 249: 162-166.

Robinson GB, Racine RJ. 1986. Interactions between septal and entorhinal inputs to the rat dentate gyrus facilitation effects. Brain Res 379: 63-67.

Rogan MT, Staubli UV, LeDoux JE. 1997. Fear conditioning induces associative long-term potentiation in the amygdala. Nature 390: 604-607.

Ronn LC, Berezin V, Bock E. 2000. The neural cell adhesion molecule in synaptic plasticity and ageing. Int J Dev Neurosci 18: 193-199.

Rosenzweig ES, Rao G, McNaughton BL, Barnes CA. 1997. Role of temporal summation in age-related long-term potentiation-induction deficits. Hippocampus 7: 549-558.

Rosenzweig MR. 1996. Aspects of the search for neural mechanisms of memory. Annu Rev Psychol 47: 1-32.

Russell RW. 1996. Continuing the search for cholinergic factors in cognitive dysfunction. Life Sci 58: 1965-1970.

Sapolsky RM. 1999. Glucocorticoids, stress, and their adverse neurological effects: relevance to aging.
Exp Gerontol 34: 721-732.

Scali C, Casamenti F, Pazzagli M, Bartolini L, Pepeu G. 1994. Nerve growth factor increases extracellular acetylcholine levels in the parietal cortex and hippocampus of aged rats and restores object recognition. Neurosci Lett 170: 117-120.

Seabrook GR, Smith DW, Bowery BJ, Easter A, Reynolds T, Fitzjohn SM, et al. 1999. Mechanisms contributing to the deficits in hippocampal synaptic plasticity in mice lacking amyloid precursor protein. Neuropharmacology 38: 349-359.

Segal M, Auerbach JM. 1997. Muscarinic receptors involved in hippocampal plasticity. Life Sci 60: 1085-1091.

Seidenbecher T, Balschun D, Reymann KG. 1995. Drinking after water deprivation prolongs "unsaturated" LTP in the dentate gyrus of rats. Physiol Behav 57: 1001-1004.

Seidenbecher T, Reymann KG, Balschun D. 1997. A post-tetanic time window for the reinforcement of long-term potentiation by appetitive and aversive stimuli. Proc Natl Acad Sci USA 94: 1494-1499.

Shankar S, Teyler TJ, Robbins N. 1998. Aging differentially alters forms of long-term potentiation in rat hippocampal area CAl. J Neurophysiol 79: 334-341.

Shapiro M. 2001. Plasticity, hippocampal place cells, and cognitive maps. Arch Neurol 58: 874-881.

Shen J, Barnes CA, Wenk GL, McNaughton BL. 1996. Differential effects of selective immunotoxic lesions of medial septal cholinergic cells on spatial working and reference memory. Behav Neurosci 110: 1181-1186.

Sherman KA, Friedman E. 1990. Pre- and postsynaptic cholinergic dysfunction in aged rodent brain regions: new findings and an interpretative review. Int J Dev Neurosci 8: 689-708.

Silva AJ, Stevens CF, Tonegawa S, Wang Y. 1992. Deficient hippocampal long-term potentiation in alpha-calcium-calmodulin kinase II mutant mice. Science 257(5067): 201-206.

Sirvio J. 1999. Strategies that support declining cholinergic neurotransmission in Alzheimer's disease patients. Gerontology 45 Suppl 1: 3-14.

Smith DE, Roberts J, Gage FH, Tuszynski MH. 1999. Age-associated neuronal atrophy occurs in the primate brain and is reversible by growth factor gene therapy. Proc Natl Acad Sci USA 96: 10893-10898. 
Smith TD, Gallagher M, Leslie FM. 1995. Cholinergic binding sites in rat brain: Analysis by age and cognitive status. Neurobiol Aging 16: 161-173.

Soininen HS, Partanen K, Pitkänen A, Vainio P, Hänninen T, Hallikainen $M$ et al. 1994. Volumetric MRI analysis of the amygdala and the hippocampus in subjects with age-associated memory impairment: correlation to visual and verbal memory. Neurology 44: 1660-1668.

Stanton PK, Sarvey JM. 1985. Blockade of norepinephrine-induced long-lasting potentiation in the hippocampal dentate gyrus by an inhibitor of protein synthesis. Brain Res 361: 276-283.

Stanton PK, Sarvey JM. 1987. Norepinephrine regulates long-term potentiation of both the population spike and dendritic EPSP in hippocampal dentate gyrus. Brain Res Bull 18: 115119.

Stemmelin J, Lazarus C, Cassel S, Kelche C, Cassel J. 2000. Immunohistochemical and neurochemical correlates of learning deficits in aged rats. Neuroscience 96: 275-289.

Stephan A, Davis S, Salin H, Dumas S, Mallet J, Laroche S. 2002. Age-dependent differential regulation of genes encoding APP and alphasynuclein in hippocampal synaptic plasticity. Hippocampus 12: 55-62.

Stevens CF, Tonegawa S, Wang Y. 1994. The role of calcium-calmodulin kinase II in three forms of synaptic plasticity. Curr Biol 4: 687-693.

Stratton KR, Baraban JM, Worley PF. 1988. Norepinephrine stimulation of adenylate cyclase potentiates protein kinase $\mathrm{C}$ action: electrophysiological studies in the dentate gyrus. Synapse 2: 614-618.

Sykova E. 2001. Glial diffusion barriers during aging and pathological states. Prog Brain Res 132:339363.

Tamaru M, Yoneda Y, Ogita K, Shimizu J, Nagata Y. 1991. Age-related decreases of the N-methyl-Daspartate receptor complex in the rat cerebral cortex and hippocampus. Brain Res 542: 83-90.

Terlau H, Seifert W. 1990. Fibroblast growth factor enhances long-term potentiation in the hippocampal slice. Eur J Neurosci 2: 973-977.

Teyler TJ, Cavus I, Coussens C, DiScenna P, Grover L, Lee YP, Little Z. 1994. Multideterminant role of calcium in hippocampal synaptic plasticity. Hippocampus 4: 623-634.

Teyler TJ, Perkins AT, Harris KM. 1989. The development of long-term potentiation in hippocampus and neocortex. Neuropsychologia 27: 31-39.

Vannucchi MG, Scali C, Kopf SR, Pepeu G, Casamenti F. 1997. Selective muscarinic antagonists differentially affect in vivo acetylcholine release and memory performances of young and aged rats. Neuroscience 79: 837-846.

Ward MT, Oler JA, Markus EJ. 1999. Hippocampal dysfunction during aging I: deficits in memory consolidation. Neurobiol Aging 20: 363-372.

Ward MT, Stoelzel CR, Markus EJ. 1999. Hippocampal dysfunction during aging II: deficits on the radial-arm maze. Neurobiol Aging 20: 373-380.

Wasling P, Hanse E, Gustafsson B. 2002. Long-term depression in the developing hippocampus: low induction threshold and synapse nonspecificity. $\mathrm{J}$ Neurosci 22: 1823-1830.

Wenk GL, Barnes CA. 2000. Regional changes in the hippocampal density of AMPA and NMDA receptors across the lifespan of the rat. Brain Res 885: 1-5.

Wenk GL, Walker LC, Price DL, Cork LC. 1991. Loss of NMDA, but not GABA-A, binding in the brains of aged rats and monkeys. Neurobiol Aging 12: 93-98.

West MJ. 1993. Regionally specific loss of neurons in the aging human hippocampus. Neurobiol Aging 14: 287-293.

Yuste R, Bonhoeffer T. 2001. Morphological changes in dendritic spines associated with long-term synaptic plasticity. Annu Rev Neurosci 24:10711089. 

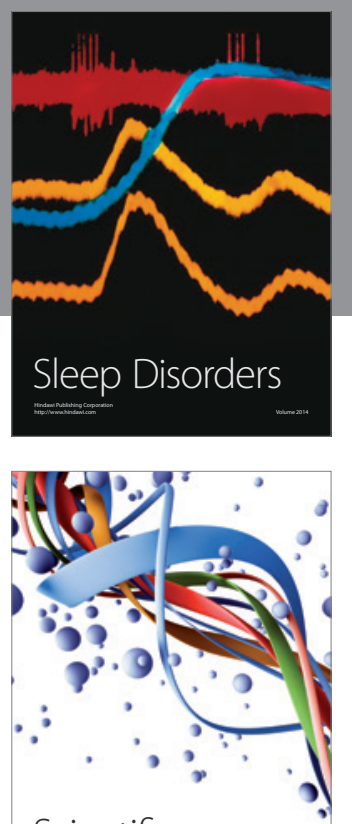

Scientifica
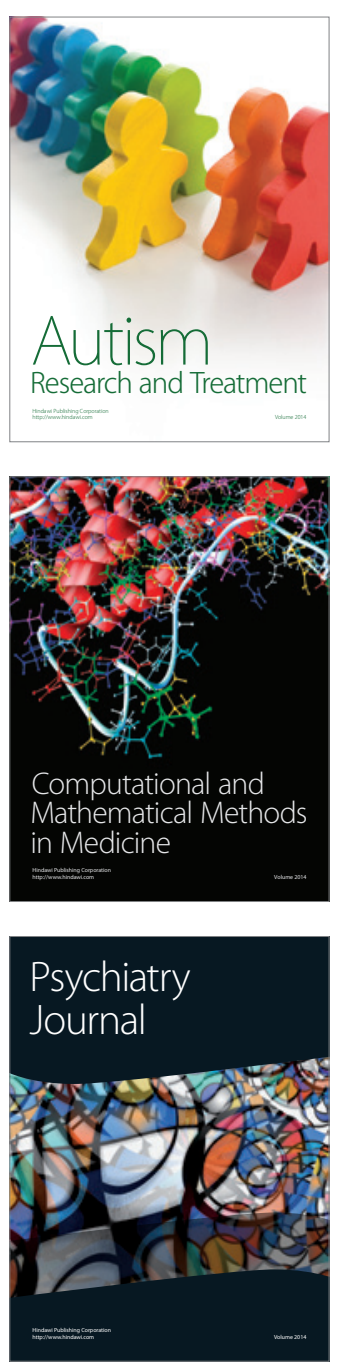
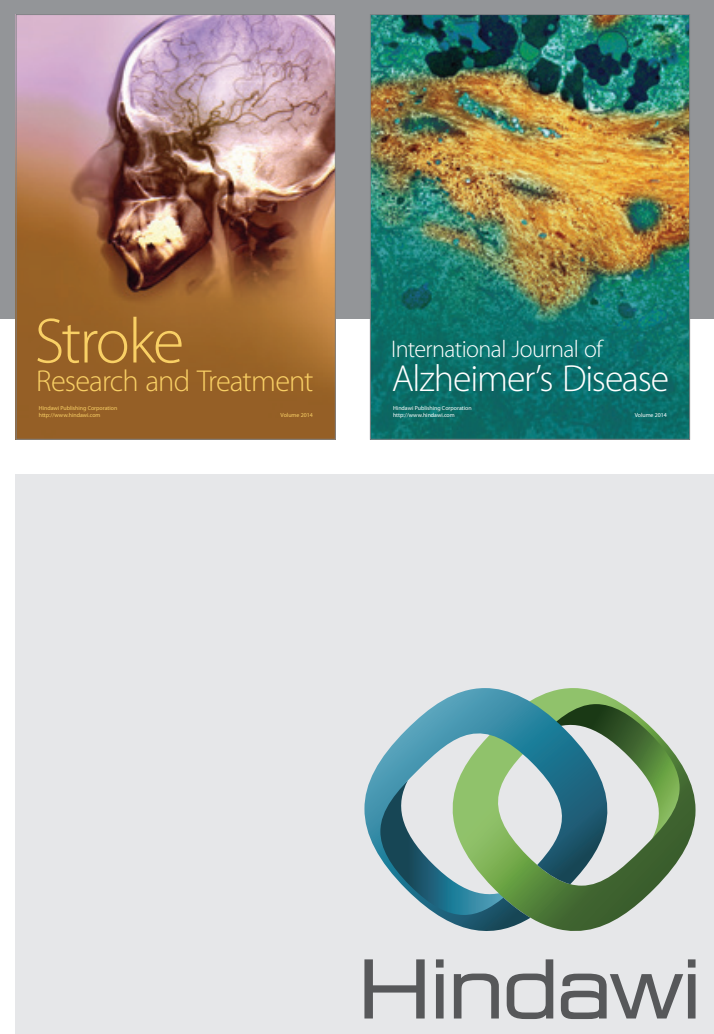

Submit your manuscripts at

http://www.hindawi.com
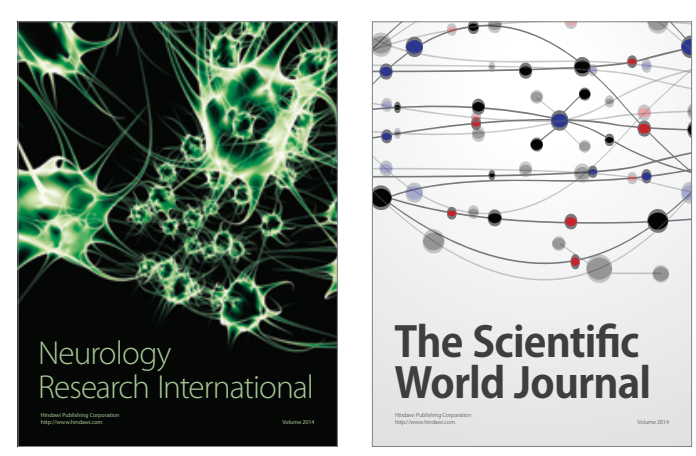

The Scientific World Journal

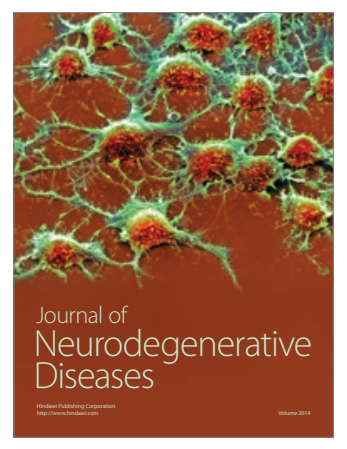

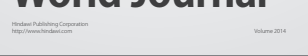

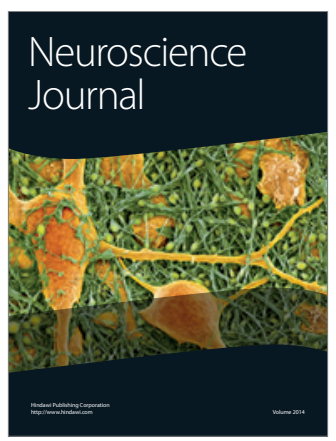

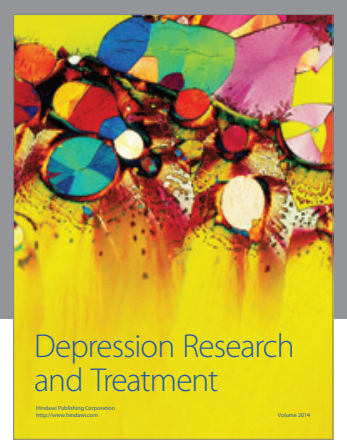
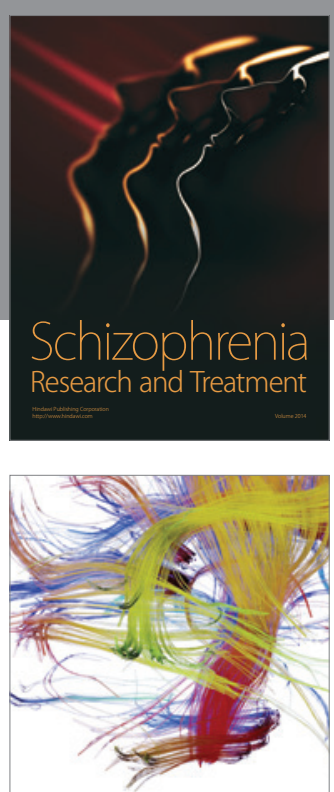

Brain Science

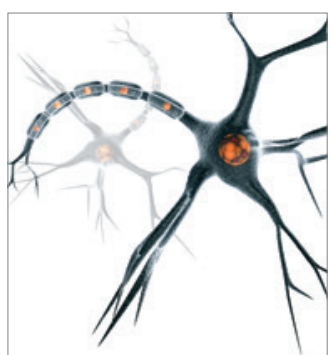

Neural Plasticity
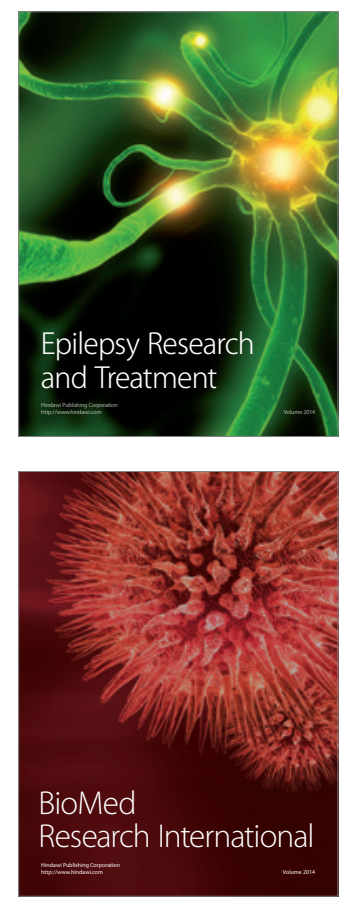

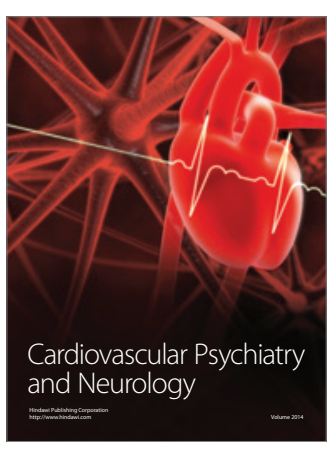

Parkinson's

Disease
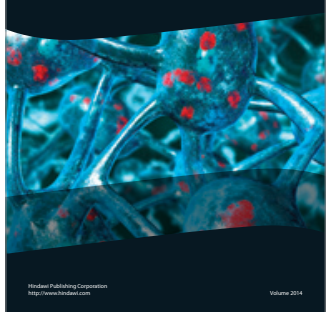